\title{
Resenha
}

\section{Guerra e Cidadania de Primeira Classe}

Por Flávio Thales Ribeiro Francisco ${ }^{1}$

LENTHZ-SMITH, Adriene Danette. Freedom Struggles: African Americans and World War I. Cambridge: Harvard University Press, 2009.

Como afirma o historiador Alexander Keyssar, ao observar a história do direito ao voto nos Estados Unidos, as guerras e os conflitos envolvendo a sociedade norteamericana sempre abriram brechas para que minorias políticas colocassem em questão a sua integração social. É exatamente este movimento que encontramos na obra de Adriene Lentz-Smith, historiadora da Duke University, sobre a participação de soldados afroamericanos na Primeira Guerra Mundial.

Lenthz-Smith não trata especificamente das experiências dos soldados afroamericanos nas frentes de batalhas da Primeira Guerra Mundial, o seu foco é a luta da população negra por direitos nos Estados Unidos, tendo como pano de fundo o conflito entre as potências europeias. Com a presença de tropas afro-americanas combatendo em favor da democracia norte-americana, aflorava a esperança pela conquista efetiva da cidadania. A historiadora percebe uma situação contraditória em que os soldados negros reforçavam as tropas norte-americanas tendo como horizonte uma cidadania de primeira classe, mas lutando por um país que difundia supremacia branca em sua política externa.

Assim que os norte-americanos resolveram participar da guerra que já havia devastado grande parte da Europa, os ativistas logo especularam sobre a participação dos soldados negros no conflito, o que poderia ser uma maneira de demonstrar a lealdade desse grupo à nação norte-americana. $\mathrm{O}$ argumento era o de que o recrutamento de afroamericanos significaria o passo inicial para a conquista de uma cidadania de primeira classe, o que engendrou inúmeras articulações para pressionar o exército dos Estados Unidos a convocá-los para a Primeira Guerra Mundial.

\footnotetext{
${ }^{1}$ Doutorando do Programa de Pós-Graduação em História Social da Universidade de São Paulo. Contato: ffrancisco@usp.br
} 
Neste contexto agitado em torno da guerra, a autora acompanha a trajetória de dois ativistas negros que não figuraram entre as grandes lideranças daquele período: Kathryn Johnson e Ely Green. Os dois tiveram posições distintas em relação ao confronto do racismo norte-americano. No caso de Johnson, a militância foi feita através da participação em diferentes organizações negras, valorizando a importância da pressão coletiva na esfera pública. Já Ely Green, que chegou a se alistar no exército norte-americano, optou por estratégias individuais, desafiando até mesmo policiais em um ambiente de supremacia racial no sul dos Estados Unidos. Entre os sete capítulos do livro, os dois ativistas negros aparecem como protagonistas e coadjuvantes de diferentes eventos que nos introduzem a um quadro histórico da militância afro-americana durante a Primeira Guerra Mundial.

A abordagem de Adriene Lenthz-Smith, no entanto, não enfoca somente o apelo afro-americano por cidadania, ela também utiliza uma perspectiva de gênero, associando a luta pela participação política dos homens negros ao reconhecimento de sua masculinidade, aqui este conceito está interligado aos de raça e nação. Entre a identificação de várias disputas em torno da noção de gênero, a autora destaca um levante de militares negros em Houston, em 1917 - antes de embarcarem para a guerra - demonstrando como os afroamericanos articularam noções de humanidade e masculinidade para definir um discurso em favor da integração negra nos Estados Unidos. Ao reagirem a atos de violência sobre mulheres negras por parte de policiais brancos, oficiais negros empunharam armas e desafiaram a estrutura social do Jim Crow atirando em cidadãos brancos da cidade. $\mathrm{O}$ levante, embora tenha excitado parte do regimento, não foi o suficiente para incitar a raiva e o senso de justiça de todos os militares negros, se desarticulando em poucas horas. Logo aqueles que haviam protagonizado o evento foram julgados e condenados. Alguns foram para a forca, outros passariam o resto da vida na cadeia, e uma parte foi sentenciada com condenações leves.

Embora o evento tenha se encerrado de forma infeliz para grande parte dos recrutas afro-americanos, o ato de carregar armas em uniformes militares foi consistente ao teatralizar a virilidade do homem negro. Lenthz-Smith, através de editoriais de jornais de leitores negros e brancos, retratou a disputa entre intelectuais negros e brancos segregacionistas sobre a narrativa do levante de oficiais do regimento negro de Houston. Todas elas se baseavam nas idéias de humanidade e masculinidade. Enquanto os brancos demonstravam o temor com a audácia de negros uniformizados que desafiavam os códigos raciais do Jim Crow em nome da cidadania, os afro-americanos martirizavam o regimento, 
falando de uma humanidade negra que se manifestava a partir de um ato de insubordinação ocorrido após a provocação à dignidade dos afro-americanos de Houston. De um lado os jornais faziam a observação sobre o perigo de se oferecer uniformes aos negros, que se sentiam no direito de "provocar" os civis brancos; de outro, enfatizavam a coragem dos oficiais em defenderem a própria honra e a das mulheres negras, conectando masculinidade negra e feminilidade negra em torno da luta pela cidadania.

A questão da masculinidade, na visão da autora, atravessou o Atlântico junto com as tropas e se manifestou, sobretudo, no contato dos soldados negros com a sociedade francesa. Além de perceberem que os soldados africanos que lutavam pela nação francesa não se organizavam em tropas segregadas como os norte-americanos, os afro-americanos ultrapassaram os limites dos "códigos raciais" dos Estados Unidos ao abordarem e serem abordados pelas mulheres francesas. Lenthz-Smith nos traz a questão do perigo da mulher francesa para a supremacia branca. A historiadora ressalta o esforço dos supremacistas em exportar o Jim Crow para as frentes de guerra na França. Era necessário que os franceses aprendessem a segregar os negros, evitando a possibilidade de degradação racial a partir da miscigenação. Os afro-americanos visualizaram na mulher francesa um desafio ao racismo, mas a aproximação não significava que os franceses não manifestassem preconceito de sua forma. A autora argumenta que havia diferenças no racismo francês e norte-americano: enquanto neste havia a preocupação em se delinear os limites entre cidadãos brancos e não brancos, no francês havia a preocupação com a criação de fronteiras entre a metrópole e a colônia; ou seja, o racismo dos europeus tinha suas prioridades.

Os dois personagens, que têm as suas trajetórias observadas na obra, além de confrontarem o racismo em território norte-americano, também participaram da Primeira Guerra Mundial. Kathryn Johnson, enquanto voluntária, e Ely Green, que integrou as tropas norte-americanas, experimentaram em solo estrangeiro a segregação racial dos Estados Unidos, manifestada no exército e em organizações voluntárias. A partir dos testemunhos de soldados negros e alguns oficiais brancos, Lenthz-Smith demonstrou como o Jim Crow se revelou em terras europeias, provocando uma disputa entre a supremacia branca e o nacionalismo negro. Cada esquina onde se instalavam os soldados norteamericanos, os brancos testavam sua autoridade colocando os oficiais negros em situações humilhantes e degradantes - como o carregamento de suprimentos em dias frios por catorze horas seguidas. Enquanto alguns soldados afro-americanos sucumbiam ao racismo e perdiam a esperança na possibilidade de uma cidadania integral, outros se apegavam a 
uma França imaginada, um ponto de partida para a ascensão de uma verdadeira democracia na América.

O fato é que a experiência na França foi preponderante para a formação política de oficiais que se tornariam ativistas. A Primeira Guerra Mundial estimulou o internacionalismo das organizações políticas afro-americanas. Green e Johnson ao retornarem da França junto com outros afro-americanos transformados pelo conflito, contribuíram de diferentes maneiras para o protesto contra supremacia branca norteamericana. Kathryn Johnson participaria de diferentes organizações do ativismo afroamericano, entre elas a UNIA - Universal Negro Improvement Association -, do radical Marcus Garvey; Ely Green, que havia adotado estratégias individuais de confronto ao racismo antes de atravessar o Atlântico, se juntou à luta de operários negros que combatiam a discriminação racial nos sindicatos norte-americanos. Adriene Lenthz-Smith, mais do que retratar a participação de soldados negros na guerra como uma possibilidade de integração social, pintou um quadro amplo de redes ativistas que foram energizadas pela guerra. Além dos dois personagens acompanhados pela autora, outras figuras citadas na obra e que tiveram trajetórias semelhantes tiveram seus horizontes políticos expandidos pela Primeira Guerra Mundial. Aqueles que retornaram aos Estados Unidos refinaram seus argumentos com observações sobre a sociedade francesa, testemunhando padrões de sociabilidades diferentes do universo segregado da nação norte-americana. Os que permaneceram ajudaram a abrir caminho para ativistas e intelectuais que formariam as redes transnacionais da militância negra na primeira metade do século XX.

Freedom Struggles está situado entre os estudos recentes que rastreiam as conexões do ativismo norte-americano com espaços mais amplos e que transcendem os limites do território nacional. Adriene Lenthz-Smith nos apresenta uma visão panorâmica de articulações da política afro-americana que são impulsionadas pela Primeira Guerra Mundial. Se de um lado a historiadora observa a participação dos soldados negros no conflito, que cumpriram o papel de testemunhas oculares, de outro acompanha a repercussão de informações sobre a segregação das tropas e um ambiente cultural distinto do norte-americano, que agitaram os ativistas negros de diferentes perspectivas políticas. $\mathrm{O}$ contexto de guerra não resolveu a questão racial nos Estados Unidos, mas inflamou uma geração que construiu as bases para a ascensão de movimentos afro-americanos consistentes. 